Egyptian Journal of Aquatic Biology \& Fisheries

Zoology Department, Faculty of Science,

Ain Shams University, Cairo, Egypt.

ISSN $1110-6131$

Vol. 25(5): 447 - 461 (2021)

www.ejabf.journals.ekb.eg

\title{
Impact of Food Values of Dried Orange Peel in Feeding the Nile Tilapia
}

Susan H. Fadda ${ }^{1}$, Raky F. Attalla ${ }^{1}$, and Marwa M. Zaher ${ }^{2}$

1-Fish Nutrition Lab. National Institute of Oceanography and Fisheries, Egypt.

2-Fish Rearing Lab. National Institute of Oceanography and Fisheries, Egypt.

*Corresponding author: suzanhassan30@yahoo.com

\section{ARTICLE INFO}

Article History:

Received: Oct. 1, 2021

Accepted: Oct. 15, 2021

Online: Oct. 26, 2021

Tilapia,

Orange peel,

Yellow corn,

Feed utilization,

Fish immunity.

\section{ABSTRACT}

The present study was conducted to evaluate the influence of three different levels of yellow corn replacer (dried orange peel) which contained highquality nutritional compounds for tilapia feeding to enhance fish performance. The inclusion levels of dried orange peel (OP) were 10, 20, and 30 percent besides the control. Fourteen weeks feeding experiment was carried out with mean initial body weight $(16.83 \pm 0.12 \mathrm{~g})$. The best growth performance parameters, feed utilization, apparent protein digestibility, and blood measurements were recorded for the fish fed moderate level of OP (20\%), followed by the third level $(30 \%)$. To attain the best fish performance and save about $30 \%$ of the yellow corn cost, the dried orange peel powder is recommended to be used in tilapia feed.

\section{INTRODUCTION}

Maize (Zea mays) is one of the most important cereal grains used for fish feeding all around the world and it has a relatively high nutritional value, and the energy value of maize may be greater than 1.1 MJ kg-1 (Song et al., 2004).

Yellow corn contains significant amounts of bioactive compounds providing desirable health benefits beyond its role as a major source of food. The health benefits of corn are not only from basic nutrients such as carbohydrates, vitamins and minerals, but also from their unique phytochemicals such as phenolicacids. A wide range of phytochemicals, such as total phenolics are found at high concentrations in corn bran and germ fractions (Siyuan et al., 2018). Corn has the highest total antioxidant activity (vitamin C) among all common grains such as rice, wheat and oats (Adom \& Liu, 2002).

Fresh fruits are important sources of energy, vitamins, minerals and fibers. The nutritional value of fruits depend mainly on the quality of these nutrients as well as their quantity. Citrus is a rich source of vitamins and some minerals (Hornick \& Weiss, 2011). Citrus belonging to family Rutaceae (Ladaniya, 2008) is considered a dominant global fruit (Jiang et al., 2014). This family has primary sources of bioactive compounds which are responsible for antioxidant and many other biological activities (Fejzić \& Ćavar, 2014). 
Citrus by-products (seeds, peels and pulp) are considered an annual huge waste load on the environment (Ramful et al., 2011; Nayak et al., 2015). However, they are promising sources of bioactive ingredients. They can be used as ingredients or food additives (O'Shea et al., 2012). During processing, the citrus peels reach about 50- 65\% of fruit weight.Citrus peels contain many valuable substances (natural products and bioactive phenolic compounds) that can be turned into raw materials forming natural byproducts that can work as a cheap antioxidant source (AbdEl-ghfar et al., 2016).

Sweet orange (Citrus sinensis) peel is common by-products (wastes) produced from processing food and juice industry. Orange peels contain flavonoids, essential oils and carotenoids. The use of economic unconventional fish diets and inexpensive feed sources is the main target of fish nutritionists. In Egypt and in many Mediterranean countries, a huge quantity of the citrus peels are left unprocessed, and some efforts were exerted to make use of these by-products in animal feed (Chedea et al., 2010; Farhat $\boldsymbol{e t}$ al., 2011). Oranges and their peels are a wide source of thiamin, foliate, vitamin $A$ in the form of betacarotene, potassium and calcium. Orange peels are used in animal feeds because they include a variety of phytonutrient compounds (that combine with the vitamin $\mathrm{C}$ contents) that give the fruit many antioxidant properties. Herperidin, for instance, a phytonutrient in oranges, is the most important flavanone that optimizes blood pressure and cholesterol in animals (Oluremi et al. 2007; Nwanna et al., 2011).

On a dry matter basis, the nutritional value of orange peels may be comparable with concentrates such as sorghum, barley and corn (Oluremi et al., 2006). The citrus fruit residues (peels), which are generally discarded as waste in the environment, can act as potential nutraceutical resources. Due to their low cost andtheir availbility in great amounts in the form of wastes, the potential of the citrus fruit peels to offer significant low-cost nutritional dietary ingredient is remarkable (Rafiqet al., 2016).

Agro by-products from fruits can substitute maize and grain as an energy component. Those bioactive substances such as phenolics, flavonoids, alkaloids and many other nitrogenous compounds that are present in fruits and vegetables have been reported to exhibit bioactivities such as antioxidant, antibacterial, antifungal and antiviral activities (Meng $\boldsymbol{e t}$ al., 2018). The nutritional value of the peels reported by Oluremiet al. (2008) showed that protein and fiber contents are $7.44-10.0 \%$ and 12.9-14.6\%, respectively depending on the process. This indicates that orange peels could replace maize in fish feeds because the protein content of maize varies from 9.0-10.0 \% (Nwanna et al., 2011) Agu (2006) also reported that orange peels replaced $20 \%$ of maize in broiler chicken. Ipinjolu (2000) mentioned that orange peels could be employed in both fish and livestock diets without affectingfish growth.

Thus, the present work aimed to evaluate the influence of partially replacing yellow corn with dried orange peel in fish feed of the tilapia on the growth performance and feed utilization parameters, physiological parameters and body indices.

\section{MATERIALS AND METHODS}

\section{Experimental design}

A 14- weeks experiment was organized to examine the effect of applying orange peel in the feed of the monosex Nile tilapia, (Oreochromis niloticus) with initial body 
weight of $16.83 \pm 0.12 \mathrm{~g}$. The study was conducted in a concrete pond of 40 $\mathrm{m}^{3}(4 \times 10 \times 1.5 \mathrm{~m})$, which was divided by using plastic nets into 4 duplicate equal parts. Each part contained 100 fish samples, and the 8 parts represented 4 dietary treatments with orange peel replacing $0 \% ; 10 \% ; 20 \% \& 30 \%$ of yellow corn (control; $\mathrm{OP}_{10}$; $\mathrm{OP}_{20} \& \mathrm{OP}_{30}$ ), respectively. The diet formula together with the chemical composition are shown in Table (1).

Fish were acclimatized under optimal conditions for 2 weeks before starting the trial. Fish were fed twice a day at 9:30 am, and 13:30 pm. Fish weight was calculated biweekly in order to adjust feeding rate ( $3 \%$ of wet weight). Water was changed twice a week.

\section{Water quality parameters}

The mean values of water quality $( \pm \mathrm{SD})$ were measured once per week at $8 \mathrm{am}$. The recorded values of water temperature was $27.9 \pm 0.4^{\circ} \mathrm{C}$; dissolved oxygen was $5-6.5 \pm$ $0.4 \mathrm{mg} / \mathrm{L} ; \mathrm{pH}$ was $7.4 \pm 0.3$. Total ammonia nitrogen values $(0.022 \pm 0.01 \mathrm{mg} / \mathrm{l})$ were measured by using a portable colorimeter. The unionized ammonia (UIA) was calculated according to the method of Zhang et al. (2018). All water quality parameters were within the acceptable range for rearing the tilapia (Makori et al., 2017).

\section{Orange peel preparation}

Orange peels were obtained from the Hero food industries (Vitrac) in Tersa, Qaliubia Governorate. Peels were left to dry at $50^{\circ} \mathrm{C}$ for $48 \mathrm{~h}$. A fine powder was obtained using a mechanical laboratory grinder and passed through a 24-mesh sieve, then packaged in polyethylene bags and stored at $4 \pm 1^{\circ} \mathrm{C}$ until further usage as a yellow corn substitute in fish diet.

\section{Determination of vitamin $C$ content in the orange peel}

The powder of orange peel $(1 \mathrm{~g})$ was extracted in $4 \%$ oxalic acid, and the solution was imparted to $100 \mathrm{ml}\left(\mathrm{V}_{1} \mathrm{ml}\right)$ and centrifuged at 12,000 rpm for $10 \mathrm{~min}$. Then, $5 \mathrm{ml}$ of the supernatant was mixed with $10 \mathrm{ml}$ of $4 \%$ oxalic acid and the solution was titrated against the dye $\left(\mathrm{V}_{2} \mathrm{ml}\right)$. Ascorbic acid was calculated according to the method of Nwanna et al. (2011) as follows:

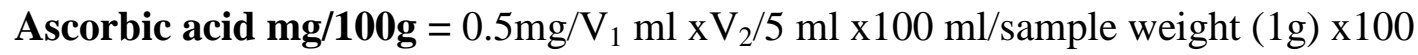

Table 1. Chemical composition of sweet orange peel and yellow corn

\begin{tabular}{|l|c|c|}
\hline \multicolumn{1}{|c|}{ Component } & Orange peel & Yellow corn \\
\hline Moisture & 83.5 & 14.0 \\
\hline Crude fiber & 40.75 & 7.3 \\
\hline Protein & 7.94 & 7.5 \\
\hline Ash & 3.01 & 1.1 \\
\hline Fat & 0.95 & 3.5 \\
\hline NFE & 47.35 & 72.9 \\
\hline Vitamin C (mg/100 g) & 238.6 & 167.40 \\
\hline
\end{tabular}




\section{Fish performance and feed utilization parameters}

Fish growth performance and feed utilization parameters were calculated according to the equations in the study of Cho and Kaushik (1985) as follows:

- Body weight gain $($ BWG, g/ fish) = [final body weight $(\mathrm{g})$ - initial body weight $(\mathrm{g})]$;

- Daily weigh gain $($ DWG, g/ fish/ day $)=[$ BWG (g) / Experimental period (days)];

- Specific growth rate $($ SGR, \%g/ day)=100 [Ln final weight-Ln initial weight]/ Experimental period (days);

- Feed conversion ratio $(\mathbf{F C R})=$ feed intake $(\mathrm{g}) /$ body weight gain $(\mathrm{g})$;

- Protein efficiency ratio $($ PER $)=$ gain in weight $(\mathrm{g}) /$ protein intake in feed $(\mathrm{g})$;

- Protein productive value $(\mathbf{P P V} \%)=100$ [protein gain in fish $(\mathrm{g}) /$ protein intake in feed $(\mathrm{g})]$;

- Survival rate\% $=100$ [Initial fish number stocked- Mortality]/ Initial fish number stocked;

Total energy content (gross energy) was measured using the equation of NRC (1981). The Metabolizable energy was determined following the study of Phillips (1972) as follows:

- Gross energy $=\{(5.65 x \% \text { Protein })+(9.45 x \% \text { Fat }) / 100\}^{*} 10^{3}$;

- Metabolizable energy $=\{(3.90 * \%$ Protein $)+(8.00 * \%$ Fat $) / 100\} * 10^{3}$;

- Protein energy ratio $(\mathbf{P} / \mathbf{E})=(\text { Crude protein } / \text { Gross energy })^{*} 10^{4}$ according to the method of Omar (1993).

Apparent protein digestibility (APD) was measured by using the method of Furukawa and Tasukahara (1966). The uneaten diet and feces were collected by siphoning once daily over the last 15 days of the trial. Feed or feces were carefully collected before first feeding. After about 30 min of feeding, uneaten feed was collected. Feces were collected separately after 2 hours then filtered and dried at $60^{\circ} \mathrm{C}$ and stored for determining the chemical composition.

\section{Physiological parameters}

\subsection{Blood parameters}

At the end of thetrial, blood samples were collected from the fish caudal vein. Blood was centrifuged at $1008 \mathrm{xg}$ for $15 \mathrm{~min}$. Samples were subjected to the determination of plasma total protein (PTP) following the method of Armstrong and Car (1964). Aspartate aminotransferase (AST) and alanine aminotransferase (ALT) were measured by the method of Rettman and Frankel (1975). Serum cholesterol was determined according to the method of Stein (1986). In addition, glucose values were calculated using the method of Trainder (1969). While, the immunoglobulins (IgM and IgD) were measured by using the method of Feinstein et al. (1985)

\subsection{Body indices}

At the end of the feeding experiment,liver and gut indices were calculated as follows:

- Hepato somatic index $(\mathrm{HSI})=($ Liver weight/ fish total weight $) * 100$;

- Gut somatic index (GSI) = (Gut weight/ fish total weight $)^{*} 100$. 


\section{Chemical analysis}

Chemical analysis of the orange peel (Table 2), the different experimental diets (Table 3) and fish body composition were conducted to measure the dry matter (DM \%). Crude protein (CP \%), ether extract (EE \%), crude fiber (CF \%), Ash (\%) and minerals of orange peel, all were examined according to the method of AOAC (2012).

Table 2.Mineral concentrates in orange peel and yellow corn

\begin{tabular}{|l|c|c|}
\hline \multirow{2}{*}{ Element } & \multicolumn{2}{|c|}{ Concentration (ppm) } \\
\cline { 2 - 3 } & Orange peel & Corn \\
\hline Potassium (K) & 157.1 & 279 \\
\hline Iron (Fe) & 123.7 & 25 \\
\hline Manganese (Mn) & 87.2 & 4.5 \\
\hline Cadcium (Ca) & 41.6 & 7.1 \\
\hline Zinc (Zn) & 22.8 & 33.45 \\
\hline Magnesium (Mg) & 13.4 & 2.18 \\
\hline Nickel (Ni) & 4.43 & 121.7 \\
\hline Copper (Cu) & 1.48 & - \\
\hline Chromium (Cr) & 1.11 & 2.9 \\
\hline Lead (Pb) & 1.23 & - \\
\hline Cadmium (Cd) & 0.24 & - \\
\hline Phosphorus (P) \% & 0.10 & $0.33 \%$ \\
\hline
\end{tabular}

\section{Statistical analysis}

The data were subjected to analysis of variance (ANOVA) using general linear models (GLM) procedure; the software used was SPSS (Version 16.0) (SPSS, 1997). Duncan's multiple range tests (Duncan, 1955) was used to compare between means of the control and the treated groups.

The model of analysis was as follows:

$\mathbf{Y}_{\mathbf{i j}}=\boldsymbol{\mu}+\mathbf{T}_{\mathbf{i}}+\mathbf{E}_{\mathbf{i j}}$

$\boldsymbol{\mu}=$ the overall mean,

$\mathbf{T}_{\mathbf{i}}=$ the effect of treatment and

$\mathbf{E}_{\mathbf{i j}}=$ the random error. 
Table 3. The formula and chemical composition of different experimental diets

\begin{tabular}{|c|c|c|c|c|}
\hline \multirow{2}{*}{ Ingredient } & \multicolumn{4}{|c|}{ Experimental diets } \\
\hline & Control & $\mathbf{O P} \mathbf{P}_{10}$ & $\mathbf{O P}_{20}$ & $\mathbf{O P}_{30}$ \\
\hline Fish meal & 15.0 & 15.0 & 15.0 & 15.0 \\
\hline Soybean meal & 30.0 & 30.0 & 30.0 & 30.0 \\
\hline Corn gluten meal & 3.0 & 3.0 & 3.0 & 3.0 \\
\hline Yellow corn & 23.0 & 20.7 & 18.4 & 16.1 \\
\hline Wheat bran & 22.5 & 22.5 & 22.5 & 22.5 \\
\hline Sun flower oil & 2.0 & 2.0 & 2.0 & 2.0 \\
\hline $\mathrm{NaCl}$ & 2.0 & 2.0 & 2.0 & 2.0 \\
\hline Vit. and Min. Premix* & 2.0 & 2.0 & 2.0 & 2.0 \\
\hline Orange peel dried & 0 & 2.3 & 4.6 & 6.9 \\
\hline Cr2O3 & 0.5 & 0.5 & 0.5 & 0.5 \\
\hline \multicolumn{5}{|c|}{ Chemical composition } \\
\hline Dry matter & 89.65 & 88.05 & 86.45 & 84.85 \\
\hline Crude protein & 28.55 & 28.56 & 28.57 & 28.58 \\
\hline Lipid & 5.16 & 5.10 & 5.04 & 4.98 \\
\hline Crude fiber & 6.02 & 6.79 & 7.56 & 8.33 \\
\hline $\begin{array}{l}\text { Nitrogen free extract (NFE } \\
\%)^{* *}\end{array}$ & 41.26 & 40.67 & 40.08 & 39.49 \\
\hline Ash & 6.19 & 6.24 & 6.28 & 6.32 \\
\hline Gross energy & 2105.4 & 2095.6 & 2090.48 & 2085.41 \\
\hline Metabolizable energy & 1526.3 & 1521.84 & 1517.4 & 1513.0 \\
\hline (P/E) ratio & 136 & 136 & 136.67 & 137.05 \\
\hline
\end{tabular}

*One kg premix contained:

Vitamins: $48 \times 10^{5} \mathrm{I} . \mathrm{U}(\mathbf{A}), 6 \times 10^{2} \mathrm{mg}\left(\mathbf{B}_{\mathbf{6}}\right), 20 \mathrm{mg}$ (biotin), $8 \times 10^{5} \mathrm{I} . \mathrm{U} .\left(\mathbf{D}_{\mathbf{3}}\right), 144 \mathrm{mg}(\mathbf{E}), 400 \mathrm{mg}$ $\left(\mathbf{B}_{1}\right), 1600 \mathrm{mg}\left(\mathbf{B}_{2}\right), 4 \times 10^{3} \mathrm{mg}$ (pantothenic acid), $4 \mathrm{mg}\left(\mathbf{B}_{12}\right), 4 \times 10^{2} \mathrm{mg}$ (niacin), $2 \times 10^{5} \mathrm{mg}$ (choline chloride), and $400 \mathrm{mg}$ (folic acid).

Minerals: $12 \times 10^{3} \mathrm{mg}$ iron, $16 \times 10^{3} \mathrm{mg}$ manganese, $12 \times 10^{2} \mathrm{mg}$ copper, $120 \mathrm{mg}$ iodine, $80 \mathrm{mg}$ cobalt, $40 \mathrm{mg}$ selenium, and $16 \times 10^{3} \mathrm{mg}$ zinc.

$* *$ Nitrogen free extract $=100-(\mathrm{CP} \%+\mathrm{EE} \%+\mathrm{CF} \%+\mathrm{Ash} \%)$

\section{RESULTS AND DISCUSSION}

\section{Growth performance of experimental fish}

The present results showed that the growth performance of the tilapia improved when fed on the three supplemented diets, especially for those fed on diet $2\left(\mathrm{OP}_{20}\right)$ followed by diet $3\left(\mathrm{OP}_{30}\right)$ when compared the control (Table 4 and Figs. 1-3).

Those results may be due to the fact that orange peel contains a rich and important content of phenolic compounds which may enhance digestion and intestinal function. Moreover, orange peel contains a huge content of fibers and pectin that improves intestinal function and health due to their physicochemical properties (Chau et al., 2005; Nwanna et al., 2011; Doan et al., 2018). The present data revealed that the three levels of orange peel acted as a direct fish growth promoter. 
Additionally, the survival rate (Fig. 3$)$ in the present findings increased $(p<0.05)$ in all fish groups fed on the three levels of orange peel compared to the control.

Table 4. Growth performance for fish fed the three levels of orange peel

\begin{tabular}{|l|c|c|c|c|}
\hline \multirow{2}{*}{ Growth parameter } & \multicolumn{4}{|c|}{ Experimental diets } \\
\cline { 2 - 5 } & Control & $\mathbf{O P}_{\mathbf{1 0}}$ & $\mathbf{O P}_{\mathbf{2 0}}$ & $\mathbf{O P}_{\mathbf{3 0}}$ \\
\hline Initial weight $(\mathbf{g})$ & $17.1^{\mathrm{a}} \pm 0.10$ & $16.4^{\mathrm{b}} \pm 0.08$ & $16.9^{\mathrm{a}} \pm 0.2$ & $16.9^{\mathrm{a}} \pm 0.12$ \\
\hline Final weight $(\mathbf{g})$ & $88.3^{\mathrm{d}} \pm 0.5$ & $91.9^{\mathrm{c}} \pm 0.53$ & $101.2^{\mathrm{a}} \pm 1.97$ & $98.7^{\mathrm{b}} \pm 0.54$ \\
\hline Body weight gain $(\mathbf{g})$ & $71.2^{\mathrm{d}} \pm 0.5$ & $78.5^{\mathrm{c}} \pm 0.51$ & $84.3^{\mathrm{a}} \pm 1.0$ & $81.8^{\mathrm{b}} \pm 0.53$ \\
\hline Daily weight gain(g/day) & $0.73^{\mathrm{d}} \pm 0.01$ & $0.77^{\mathrm{c}} \pm 0.01$ & $0.86^{\mathrm{a}} \pm 0.02$ & $0.83^{\mathrm{b}} \pm 0.03$ \\
\hline Specific growth rate & $1.68^{\mathrm{c}} \pm 0.020$ & $1.76^{\mathrm{b}} \pm 0.010$ & $1.83^{\mathrm{a}} \pm 0.011$ & $1.80^{\mathrm{a}} \pm 0.003$ \\
\hline Survival rate $(\%)$ & $93^{\mathrm{c}}$ & $97^{\mathrm{b}}$ & $98^{\mathrm{a}}$ & $99^{\mathrm{a}}$ \\
\hline
\end{tabular}

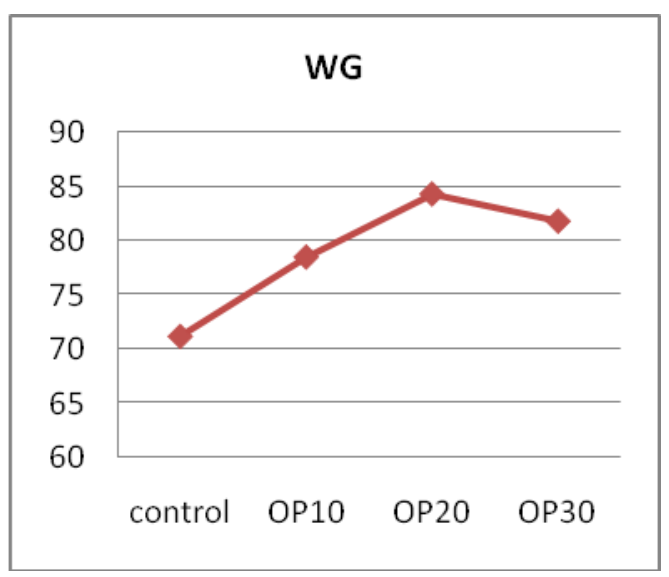

Fig. 1. Mean weight gain

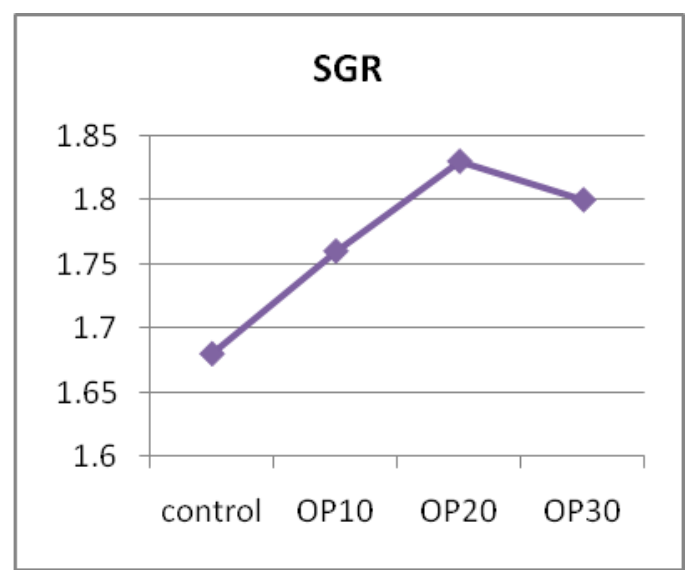

Fig. 2. Specific growth rate

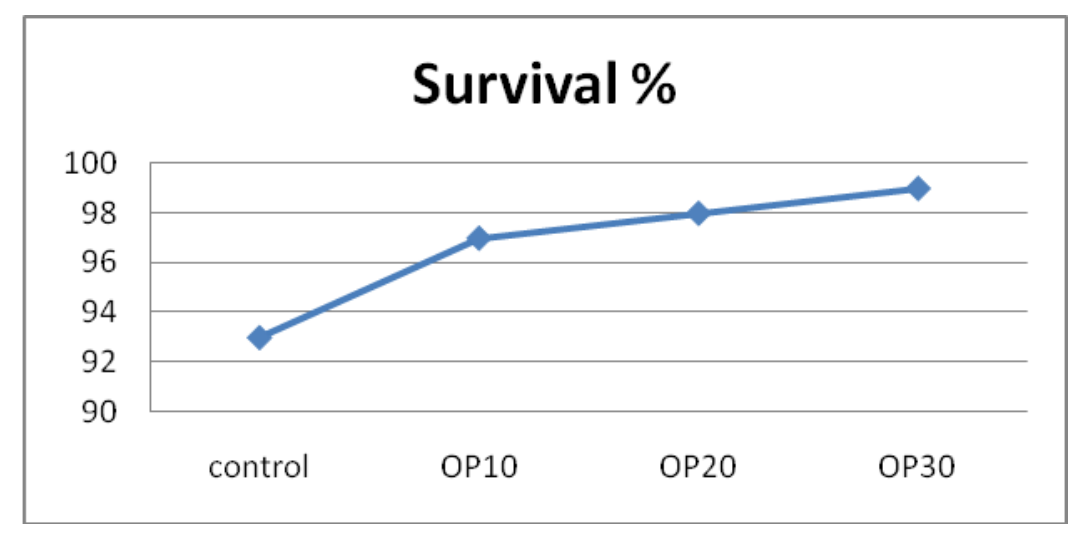

Fig. 3. Fish survival rate

\section{Feed utilization}

The best values $(79.02 \%, 42.96 \%$ and 2.58$)$ of apparent protein digestibility, protein productive value and protein efficiency ratio, respectively, were found for fish fed on $\mathrm{OP}_{20}$, accompanied with the optimal values of feed conversion ratio and feed consumed withvalues of $1.59 \& 133.63 \mathrm{~g}$, respectively (Figs. 4 \& 5). 
Table 5. Feed utilization of Nile tilapia fed yellow corn replacer (OP)

\begin{tabular}{|l|c|c|c|c|}
\hline \multirow{2}{*}{\multicolumn{1}{c|}{ Parameter }} & \multicolumn{4}{c|}{ Experimental diets } \\
\cline { 2 - 5 } & Control & $\mathbf{O P}_{\mathbf{1 0}}$ & $\mathbf{O P}_{\mathbf{2 0}}$ & $\mathbf{O P}_{\mathbf{3 0}}$ \\
\hline Final weight & $88.3^{\mathrm{d}} \pm 0.67$ & $91.9^{\mathrm{c}} \pm 0.53$ & $101.2^{\mathrm{a}} \pm 1.97$ & $98.7^{\mathrm{b}} \pm 0.58$ \\
\hline Food consumed & $119.99^{\mathrm{d}} \pm 0.5$ & $122.87^{\mathrm{c}} \pm 1.0$ & $133.63^{\mathrm{a}} \pm 0.51$ & $130.93^{\mathrm{b}} \pm 0.53$ \\
\hline Feed conversion ratio & $1.69^{\mathrm{c}} \pm 0.01$ & $1.63^{\mathrm{b}} \pm 0.02$ & $1.59^{\mathrm{a}} \pm 0.01$ & $1.60^{\mathrm{a}} \pm 0.03$ \\
\hline Protein efficiency ratio & $2.32^{\mathrm{c}} \pm 0.020$ & $2.44^{\mathrm{b}} \pm 0.011$ & $2.55^{\mathrm{a}} \pm 0.010$ & $2.58^{\mathrm{a}} \pm 0.003$ \\
\hline PPV \% & $33.37^{\mathrm{c}} \pm 0.95$ & $37.20^{\mathrm{b}} \pm 0.89$ & $42.96^{\mathrm{a}} \pm 0.94$ & $42.96^{\mathrm{a}} \pm 0.86$ \\
\hline APD & $68.03^{\mathrm{d}} \pm 1.01$ & $77.03^{\mathrm{c}} \pm 0.99$ & $79.02^{\mathrm{a}} \pm 1.02$ & $77.8^{\mathrm{b}} \pm 1.08$ \\
\hline
\end{tabular}

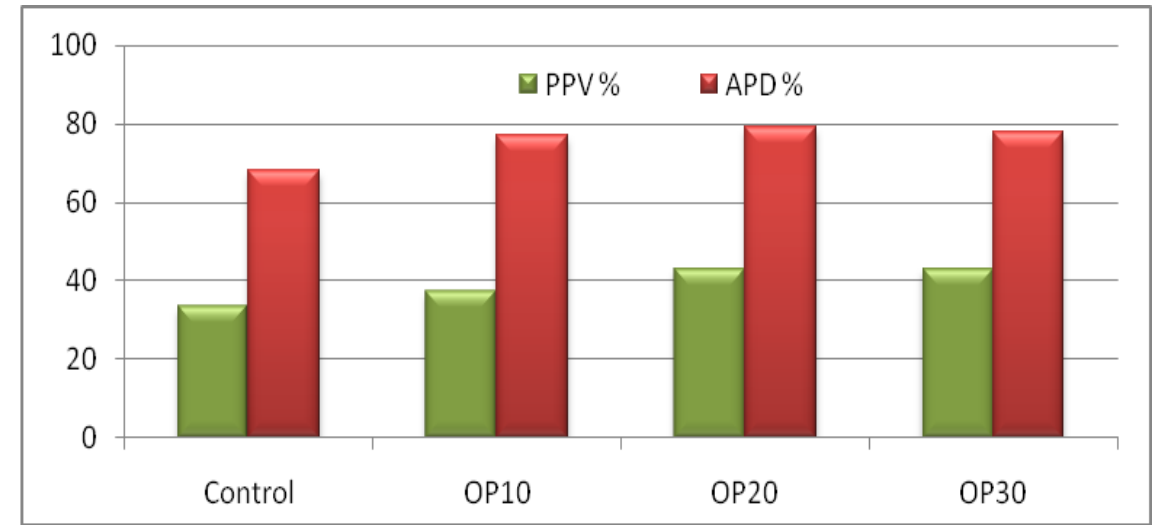

Fig. 4. Apparent protein digestibility (APD) and protein productive value (PPV)

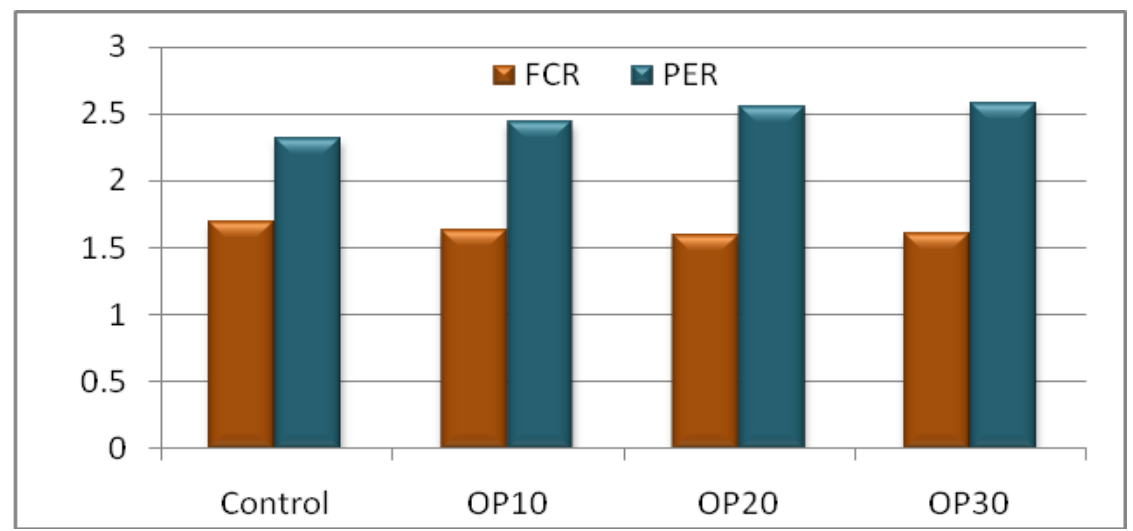

Fig. 5. Feed conversion ratio (FCR) and protein efficiency ratio (PER)

The present results cleared that dietary inclusion of orange peel levels improved fish feed utilization, indicating that orange peel acts as a fish appetizer.

The huge fiber content of the yellow corn replacer could improve the nutrient digestibility of the diets. On the other hand, high lipid and carbohydrate levels act as dietary sources (Nwanna et al., 2011).Additionally, Salem and Abdel-Ghany (2018) noted that, the orange peel powder in the tilapia diets $(2 \%)$ enhanced the digestion and nutrient absorption. 


\section{Body chemical composition}

The results showed that, the lipid content of the fish showed a decreasing trend with the inclusion of orange peels, where the highest protein and lowest lipid content were recorded for the fish fed $\mathrm{OP}_{20}$ and $\mathrm{OP}_{30}$. Therefore, fat reducing in the muscle of fish fed orange peel improved the flesh quality because of the reduction in the cholesterol levels of the fish. This application could fairly be adjusted to produce low cholesterol fishes for people with heart problems (Table 6).

Table 6. Effect of different experimental diets on carcass composition of Nile tilapia

\begin{tabular}{|l|c|c|c|c|}
\hline \multirow{2}{*}{\multicolumn{1}{c|}{ Body analysis }} & \multicolumn{4}{c|}{ Experimental diets } \\
\cline { 2 - 5 } & Control & $\mathbf{O P}_{\mathbf{1 0}}$ & $\mathbf{O P}_{\mathbf{2 0}}$ & $\mathbf{O P}_{\mathbf{3 0}}$ \\
\hline Protein (\%) & $56.1^{\mathrm{c}} \pm 1.05$ & $58.42^{\mathrm{b}} \pm 0.84$ & $60.94^{\mathrm{a}} \pm 1.12$ & $60.6^{\mathrm{a}} \pm 1.06$ \\
\hline Lipid (\%) & $22.4^{\mathrm{a}} \pm 0.80$ & $18.3^{\mathrm{b}} \pm 0.63$ & $17.7^{\mathrm{c}} \pm 0.45$ & $17.83^{\mathrm{c}} \pm 0.47$ \\
\hline Ash (\%) & $18.85^{\mathrm{c}} \pm 0.66$ & $19.5^{\mathrm{b}} \pm 1.01$ & $19.75^{\mathrm{a}} \pm 0.80$ & $19.63^{\mathrm{ab}} \pm 0.12$ \\
\hline NFE (\%) & $2.65^{\mathrm{b}} \pm 0.10$ & $3.78^{\mathrm{a}} \pm 0.11$ & $1.61^{\mathrm{d}} \pm 0.05$ & $1.94^{\mathrm{c}} \pm 0.11$ \\
\hline Moisture (\%) & $74.34^{\mathrm{a}} \pm 1.22$ & $73.94^{\mathrm{b}} \pm 1.06$ & $72.4^{\mathrm{d}} \pm 0.81$ & $72.71^{\mathrm{c}} \pm 0.78$ \\
\hline DM (\%) & $25.66^{\mathrm{c}} \pm 0.84$ & $26.06^{\mathrm{b}} \pm 0.67$ & $27.6^{\mathrm{a}} \pm 0.90$ & $27.29^{\mathrm{a}} \pm 0.75$ \\
\hline Gross energy & $5286.5^{\mathrm{a}} \pm 2.35$ & $5030.1^{\mathrm{c}} \pm 1.54$ & $5115.8^{\mathrm{b}} \pm 2.11$ & $5108.8^{\mathrm{c}} \pm 2.31$ \\
\hline Metabolizable energy & $3979.9^{\mathrm{a}} \pm 2.84$ & $3742.4^{\mathrm{d}} \pm 1.83$ & $3792.7^{\mathrm{c}} \pm 2.04$ & $3789.8^{\mathrm{b}} \pm 1.91$ \\
\hline (P/E) ratio & $106.12 \mathrm{c} \pm 1.01$ & $116.14^{\mathrm{b}} \pm 1.24$ & $119.12^{\mathrm{a}} \pm 1.56$ & $118.62^{\mathrm{a}} \pm 1.53$ \\
\hline
\end{tabular}

Thus, orange peels could be used to produce low fat fishes that would be beneficial for people with cardiovascular problems (Nwanna et al., 2011). Moisture recorded content fluctuated insignificantly $(\mathrm{p}>0.05)$ through the three fish groups. The result cleared that, dry matter and ash content were increased for fish fed $\mathrm{OP}_{20}$ and $\mathrm{OP}_{30}$. High percent of dry matter and ash content may owe to the high mineral content of orange peel powder that may increase mineralization in fish muscles (Nwanna et al., 2011). The high lipid, fiber and carbohydrate contents of orange peel feedstuffs are indications that the peels could serve as a good source of dietary energy in fish feeds.

\section{Physiological parameters}

\subsection{Body indices}

Fig (6) shows that the recorded body indices were affected by the experimental diets; the highest and lowest liver and gut indices were recorded for fish fed diet 1 . Those results may be attributed to the fiber content, phenolic compounds, and pectin that may improve intestinal function and fish health (Chau et al., 2005; Doan et al., 2018). In such a case, an increase in the level of replacement would be recorded leading to a decline in the hepatic index.

\subsection{Hematological parameters}

The present results explained that using orange peel as an additive improved the plasma total protein and optimized liver health (AST and ALT) of the treated fish. Moreover, orange peel additive enhanced the immunity of the tested fish accompanied with the declining trend in plasma glucose and cholesterol. The best plasma total protein value (3.91) was recorded for those fed the $\mathrm{OP}_{30}$ (Table 7).

Terpstra et al. (2002) and Figuerola et al. (2005) stated that, some physiological functions of the fiber content in the dried orange peel may reduce blood cholesterol and 
glucose level. Furthermore, orange peel essential oil contains terpenes compounds which are effective in reducing plasma cholesterol levels (Dillard \& German, 2000).

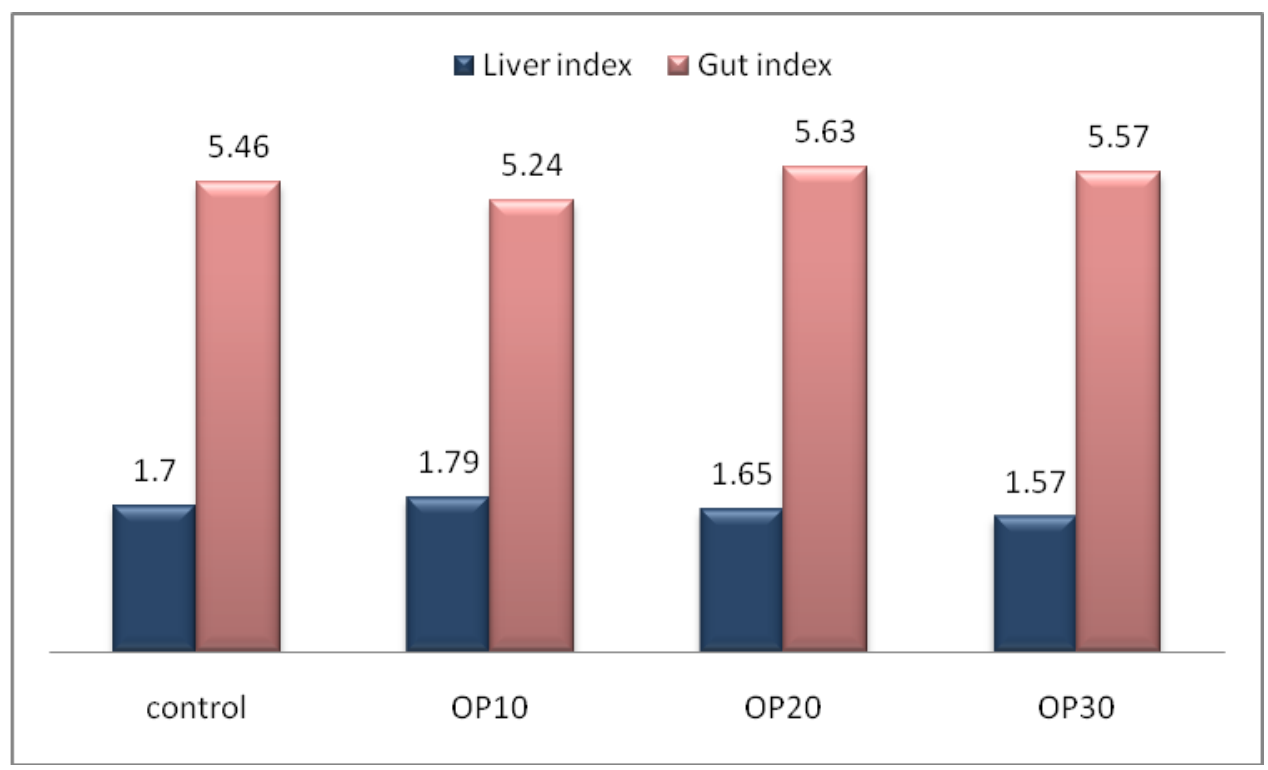

Fig. 6. Body indices of experimental fish

Table 7. Hematological condition of the fish fed the replacer

\begin{tabular}{|l|c|c|c|c|}
\hline \multirow{2}{*}{ Blood parameter } & \multicolumn{4}{c|}{ Experimental diets } \\
\cline { 2 - 5 } & Control & $\mathbf{O P}_{\mathbf{1 0}}$ & $\mathbf{O P}_{\mathbf{2 0}}$ & $\mathbf{O P}_{\mathbf{3 0}}$ \\
\hline Glucose (mg/dl) & $94.8^{\mathrm{a}} \pm 1.03$ & $81.32^{\mathrm{b}} \pm 1.10$ & $78.73^{\mathrm{c}} \pm 1.05$ & $76.0^{\mathrm{d}} \pm 1.02$ \\
\hline Cholesterol (mg/dI) & $119.8^{\mathrm{a}} \pm 1.12$ & $108.22^{\mathrm{b}} \pm 1.10$ & $105.13^{\mathrm{c}} \pm 1.03$ & $105.17^{\mathrm{c}} \pm 1.05$ \\
\hline Plasma total protein & $3.32^{\mathrm{c}} \pm 0.05$ & $3.85^{\mathrm{b}} \pm 0.05$ & $3.89^{\mathrm{a}} \pm 0.03$ & $3.91^{\mathrm{a}} \pm 0.04$ \\
\hline AST & $140.2^{\mathrm{a}} \pm 2.01$ & $128.11^{\mathrm{b}} \pm 1.72$ & $123.40^{\mathrm{c}} \pm 1.82$ & $124.75^{\mathrm{c}} \pm 1.93$ \\
\hline ALT & $70.8^{\mathrm{a}} \pm 1.55$ & $65.45^{\mathrm{b}} \pm 1.17$ & $61.74^{\mathrm{d}} \pm 0.84$ & $62.17^{\mathrm{c}} \pm 0.77$ \\
\hline IgM & $10.75^{\mathrm{a}} \pm 0.34$ & $8.94^{\mathrm{b}} \pm 0.31$ & $8.67^{\mathrm{c}} \pm 0.12$ & $8.37^{\mathrm{d}} \pm 0.11$ \\
\hline IgD & $134.65^{\mathrm{d}} \pm 1.11$ & $145.55^{\mathrm{c}} \pm 1.32$ & $156.52^{\mathrm{b}} \pm 1.41$ & $158.35^{\mathrm{a}} \pm 1.54$ \\
\hline
\end{tabular}

The present results revealed that, orange peel enhanced the liver enzyme activities and the immunoglobulins ( $\operatorname{IgM} \& \operatorname{IgD}$ ). Those findings may be due to the presence of some bioactive components such as phenols, amino acids, essential oils, pectin, carotenoids, flavonoids, and vitamin $\mathrm{C}$ in orange peel which have a positive biochemical functional effects as antioxidant agents, (Assini et al., 2013; M'hiri et al., 2015). The essential oils of orange peel have recorded beneficial effects on growth and immune system of the tilapia (Acaret al., 2015). All those compounds have positively affected the enzymes activities, enhanced nutrients digestibility and food absorption, and thus improved fish growth (Al-Saadi et al., 2009; Immanuel et al., 2009; Citarasu, 2010; Hashemi \& Davoodi, 2011; Fadda \& Raky, 2021). In addition, these bioactive substances can promote biological activities and act as antistress and appetizer, adding to 
their role in enhancing the immunity system and antioxidants (Citarasu, 2010; Yilmaz, 2019; Raky et al., 2021).

The current findings showed that, the different levels in OP as a yellow corn replacer enhanced liver enzyme activities and immunoglobulins' concentrations. Vitamin $\mathrm{C}$ in orange peel plays a positively effective role and act as an antioxidant for cell integrity.

\section{Economic profit.}

Orange peels contain some important minerals and also huge amount of vitamin C. This advantage can be used in reducing supplemental minerals and vitamins in the diet, which could reduce the cost of feed production (Nwanna et al., 2011).

Combined with maize, orange peels can reduce the oxidation of dietary protein for energy that has a protein sparing ability, which, in return, would minimize the quantity/cost of dietary protein (Hanley 1991; Nwanna et al. 2003).

\section{REFERENCES}

A.O.A.C. (2012)."Official Methods of Analysis of the Association of Official Analytical Chemistry."(A.O.A.C.)International, $19^{\text {th }}$ ed., Gaithersburg, Maryland, USA.

Abd El-ghfar, M.H.A.; Ibrahim, H. M.; Hassan, I. M.; Abdel Fattah, A.A. and Mahmoud, M. H. (2016). Peels of lemon and orange as value-added ingredients: chemical and antioxidant properties. International Journal of Current Microbiology and Applied Sciences, 5(12): 777-794.

Acar, Ü.; Kesbiç, O.S.; Yılmaz, S.; Gültepe, N. and Türker, A.(2015). Evaluation of the effects of essential oil extracted from sweet orange peel (Citrus sinensis) on growth rate of tilapia (Oreochromis mossambicus) and possible disease resistance against Streptococcus iniae. Aquaculture, 437: 282-286.

Adom, K.K. and Liu, R.H. (2002). Antioxidant activity of grains, J. Agric. Food Chem., 50: 6182-6187.

Agu, P.(2006). Nutritional evaluation of sweet orange (Citrus sinensis) peel as a feed resource for broiler chickens. MSc Thesis. University of Agriculture, Makurdi, Nigeria.

Al-Saadi, N.M.; Ahmad, N.S. and Sa'eed, S.E. (2009). Determination of some chemical compounds and the effect of oil extract from orange peel on some pathogens. Journal of Kerbala University, 7: 33-39.

Armstrong, W.D. and Carr, C.W. (1964). Physiological Chemistry Laboratory Directions. ( $3^{\text {rd }}$ ed.). Burges Publishing Co. Minneapolis, Minnesota.

Assini, J.M.; Mulvihill, E.E. and Huff, M.W. (2013). Citrus flavonoids and lipid metabolism .Curr. Opin. Lipidol, 24(1):34-40. 
Chau, C.F.; Sheu, F.; Huang, Y.L. and Su, L.H.(2005). Improvement in intestinal function and health by the peel fiber derived from Citrus sinensis L cv Liucheng. J. Sci. Food Agric., 85: 1211-1216.

Chedea, V.S.; Braicu, C. and Socaciu, C. (2010). Antioxidant / prooxidant activity of a polyphenolic grape seed extract. Food Chem, 121(1):132-139.

Cho, C. Y. and Kaushik, S. J. (1985).Effects of protein intake on net metabiliable and net energy values of fish diets. In: Nutrition and Feeding in Fish, Academic Press, London, 95- 117.

Citarasu, T. (2010). Herbal biomedicines: a new opportunity for aquaculture industry. Aquaculture International, 18: 403-414.

Dillard, C.J. and German, J.B. (2000). Phytochemicals: nutraceuticals and human health. J. Sci. Food Agric., 80(12): 1744-1756.

Doan, H.V.; Hoseinifar, S.H.; Elumalai, P.; Tongsiri, S.; Chitmanat, C.; Jaturasitha S. and Doolgindachbaporn, S. (2018). Effects of orange peels derived pectin on innate immune response, disease resistance and growth performance of Nile tilapia (Oreochromis niloticus) cultured under indoor biofloc system, Fish and Shellfish Immunology, doi: 10.1016/j.fsi.2018.05.049.

Duncan, D.B. (1955).Multiple ranges and multiple F-tests. Biometrics, 11: 1-42.

Fadda, S.H. and Raky, F.A. (2021). Effect of Chlorella-based diets on growth of the silver carp, Hypophthalmichthys molitrix. Egyptian Journal of Aquatic Biology \& Fisheries, 25(4): 917-928.

Farhat, A.; Fabiano-Tixier, A. S.; El Maataoui, M.; Maingonnat, J. F.; Romdhane, M. and Chemat, F. (2011). Microwave steam diffusion for extraction of essential oil from orange peel: Kinetic data, extract's global yield and mechanism, Food Chem.,125: 255-261.

Feinstein, S.; Akov, Y.; Lachmi, B. E.; Lehrer, S.; Rannon, L. and Katz, D.(1985). Determination of human IgG and IgM class antibodies to West Nile virus by enzyme linked immunosorbent assay (ELISA), J Med. Virol., 17(1): 63-72.

Fejzić, A. and Ćavar, S. (2014). Phenolic compounds and antioxidant activity of some citruses. Bull. Chem. Technol. Soc. Bosnia Herzegovina, 42: 1-4.

Figuerola, F.; Hurtado, M.L.; Estevez, A.M.; Chiffelle, I. andAsenjo, F. (2005). Fibre concentrates from apple pomace and citrus peel as potential fiber sources for food enrichment. Food Chem., 91: 395- 401.

Furukawa, A. and Tasukahara, H. (1966). On the acid digestion method for determination of Chromic Oxide as an index substance in the study of digestibility of fish feed. Bulletin of Japanese Society of Sintific fisheries, 32:502-506. 
Hanley, F. (1991). Effects of feeding supplementary diets containing varying levels of lipid on growth, food conversion and body composition of Nile tilapia, Oreochromis niloticus (L). Aquaculture,93:323-334.

Hashemi, S. R. and Davoodi, H. (2011). Herbal plants and their derivatives as growth and health promoters in animal nutrition. Veterinary Research Communications, 35: 169180.

Hornick, B.A. and Weiss, L. (2011). Comparative nutrient analysis of commonly consumed vegetables. Nutr Today., 46:130-7.

Immanuel, G.; Uma, R. P.; Iyapparaj, P.; Citarasu, T.; Peter, S. M. P.; Babu, M. M. and Palavesam, A. (2009). Dietary medicinal plant extracts improve growth, immune activity and survival of tilapia Oreochromis mossambicus. Journal of Fish Biology, 74(7): $1462-1475$.

Ipinjolu, J. (2000). Performance of juvenile orange koi carp (Cyprinus carpioL.) fed diets supplemented with sweet orange peel. Journal of Veterinary Science,2:228-229.

Jiang, N.; Jin, L.F.; Teixeira da Silva, J.A.; IsIam, M.Z.; Gao, H-W.; Liu, Y-Z. and Peng, S.A. (2014). Activities of enzymes directly related with sucrose and citric acid metabolism in citrus fruit in response to soil plastic film mulch. Sci. Hortic., 168: 73-80.

Ladaniya, M.S. (2008). Citrus Fruit: Biology, Technology and Evaluation. Elsevier Inc., Atlanta, USA, 1-10.

M'hiri, N.; Ioannou, I.; Ghoul, M. and Boudhrioua, N. M. (2015). Proximate chemical composition of orange peel and variation of phenols and antioxidant activity during convective air drying. Journal of new sciences, JS-INAT (9): 881-890.

Makori, A. J.; Abuom, P. O.; Kapiyo, R.; Anyona, D. N. and Dida, G. O. (2017).Effects of water physico-chemical parameters on tilapia (Oreochromis niloticus) growth in earthen ponds in Teso North Sub-County, Busia County. Fisheries and Aquatic Sciences, 20: 30 .

Meng, X.H.; Liu, C.; Fan, R.; Zhu, L.F.; Yang, S.X.; Zhu, H.T.; Wang, D.; Yang, C.R. and Zhang, Y.J. (2018). Antioxidative flavan-3-ol dimers from the leaves of Camellia fangchengensis. J. Agric. Food Chem., 66: 247-254.

National Research Council (NRC) (1981). Nutrient requirements of cold water fishes, No. 16. Nutrient requirements of domestic animals. National Academy Press, Washington D.C., 63 pp.

Nayak, B.; Dahmoune, F.; Moussi, K.; Remini, H.; Madani, K.; Dairi, S.; Aoun, O. and Khodir, M. (2015). Comparison of microwave, ultrasound and accelerated assisted solvent extraction for recovery of polyphenols from Citrus sinensis peels. Food Chem., 187: 507-516. 
Nwanna, L.; Fagbenro O. and Kehinde.(2003). Effect of substitution of acha for maize on the growth and economic performance of Oreochromics niloticus. Journal of Food, Agriculture and Environment,1(3\&4):100-103.

Nwanna, L.C; Akomolafe, F.; Oboh, G. and Lajide, L. (2011). Effect of the replacement of yellow maizewith Saccharomyces cerevisae fermented orange peels on the growth and nutrient utilization of African Catfish, Clarias gariepinus (Burchell, 1822). World Aquaculture, 16-21.

Oluremi, O.; Mou, P. and Adenkola, A. (2008). Effect of fermentation of sweet orange (Citrus sinensis) fruit peel on its maize replacement value in broiler diet. Livestock Res. for Rural Devel.20: 20.

Oluremi, O.; Ngi, J. and Andrew, I. (2007). Phytonutrients in citrus fruit peel meal and nutritional implication for livestock production. Livestock Research for Rural Development, 19 (89).

Oluremi, O.I.A; Ojighen, V.O. and Ejembi,. E. H. (2006). The nutritive potential of sweet orange (Citrus sinensis) in broiler production. International Poultry Science, 5(7):613-617.

Omar, E.A. (1993). Optimum protein to energy ratio for Nile tilapia (Oreocromis niloticus) Fingerlings. Alex. J. Agric. Res., 39: 73-93.

O'Shea, N.; Arendt, E.K. and Gallagher, E. (2012). Dietary fiber and phytochemical characteristics of fruit and vegetable by-products and their recent applications as novel ingredients in food products. Innovative Food Sci. Emerging Technol., 16: 1-10.

Phillips, A.M. (1972). Calorie and energy requirements in fish nutrition (J.E. Halver Ed.). Academic press. New York, pp. 2-28.

Rafiq, S.; Kaul, R.; Sofi, S.A.; Bashir, N.; Nazir, F. and Nayik, G. A. (2016). Citrus peel as a source of functional ingredient: A review. Journal of the Saudi Society of Agricultural Sciences, DOI: 10.1016/j.jssas.2016.07.006.

Raky, F. A.; Fadda, S. H. and Salah El-Dein, S. A. (2021). Effects of some feed additives on growth performance and physiological parameters of Oreochromis niloticus. Egyptian Journal of Aquatic Biology \& Fisheries, 25(4):807-821.

Ramful, D.; Tarnus, E.; Aruoma, O.I.; Bourdon, E. and Bahorun, T. (2011). Polyphenol composition, vitamin $\mathrm{C}$ content and antioxidant capacity of Mauritian citrus fruit pulps. Food Res. Int., 44: 2088-2099.

Rettman, S. and Frankel, S. (1957). A colorimetric determination of glutamic oxaloacetic and glutamic pyruvic transaminase. J. Clin. Pathol.,28(1):56-63. 
Salem, M. and Abdel-ghany, H.M. (2018). Effects of dietary orange peel on growth performance of Nile tilapia (Oreochromis niloticus) fingerlings. Aquac. Stud., 18(2): $127-134$.

Siyuan, S.; Tong, L. and RuiHai, L.(2018). Corn phytochemicals and their health benefits. Food Science and Human Wellness, 7: 185-195.

Song, G.L.; Li, D.F.; Piao, X.S.; Chi, F.; Chen, Y. and Moughan, P.J. (2004). True amino acid availability in Chinese high-oil corn varieties determined in two types of chickens. Poult., Sci., 83: 683-688.

SPSS, (1997). Statistical Package for the Social Sciences, Version 16, SSS in Ch, ChiUSA.

Stein, E.A. (1986). Text book of clinical chemistry N. W. Tietz (Ed.) W.B. Saunders Co. Philadelphia, 1818- 1829 pp.

Terpstra, A.H.; Lapre, J.A.; Vries, H.T. and Beynen, A.C. (2002). The hypocholesterolemic effect of lemon peels, lemon pectin, and the waste stream material of lemon peels in hybrid F1B hamsters. Eur. J. Nutr, 41(1): 19-26.

Trinder, P. (1969). Determination of glucose in blood using glucose oxidase with an alternative oxygen acceptor. Annual Clin.Biochem, 6: 24-27.

Yilmaz, S., (2019). Effects of dietary blackberry syrup supplement on growth performance, antioxidant, and immunological responses, and resistance of Nile tilapia, Oreochromis niloticus to Plesiomonass higelloides. Fish Shellfish Immunol, 84: 11251133.

Zhang, L.; Xu, E. G.; Li, Y.; Liu, H.; Vidal- Dorsch, D. E. and Giesy, J. P. (2018). Ecological risks posed by ammonia nitrogen (AN) and un-ionized ammonia (NH3) in seven major river systems of China. Chemosphere, 202: 136-144. 